\title{
CRIMINAL MILES AND PHENOMENOLOGICAL ASPECTS OF THE CRIMINALISTICS INTELLIGENCE SOURCES
}

The paper is based on research conducted by the author in the last decades of the twentieth century and the first decade of the third millennium, the modern scientific theory of crime investigation. The author's intention is to complete the huge gap that exists today in our scientific crime literature on the phenomenology of criminalistics intelligence sources. The presence of scientific and technical isolationist and conservative pragmatism in criminalistics theory in us, with whom I have never lied, accordingly, I have tried to work more fully convey the latest scientific views on foreign theory of criminology criminalistics intelligence sources as the primary tool for understanding, recognition and decoding of occurrence in the criminal milieu. From the above it is quite logical and scientific methodology established by first larly exposed to the general approach among law enforcement theory, the criminal underworld, and then access the research of criminalistics intelligence sources, through their determination to categorize the movement and management. From the results, the findings suggest that the traditional model definition, recruitment, management and installation source in a criminal milieu, which applies to us, abandoned for more than three decades of contemporary crime research and professional literature and practice in the world. Furthermore, the results indicate that it is of decisive importance to the understanding of criminalistics intelligence sources, methods of installation, movement models and management resources, to the criminal milieu could understand phenomena that are not visible, and carry with them the challenges, risks and threats. Not more contemporary understanding of the needs of society to counter the criminal activities of individuals or groups, it is enough to have informers or collaborators. Today, the world of crime must confront numerous, well-organized and professional criminalistics intelligence activities.

Key words: criminal milieu, criminalistics intelligence source, recruiting, dimensioning, source motion

Dragan Manojlović, PhD, Associate Professor at the Faculty of Law, Public Administration and Security, Megatrend University, Belgrade, e-mail: dmanojlovic@megatrend.edu.rs 


\section{Introductory remarks about criminal milieu}

It is often argued in crime-scientific thought, the history of the criminal milieu, only one teacher. This belief is even more right about him not getting out one important fact: each is a criminal event, individual, unique, different from all others. Standing by in operational law enforcement records and they have something that connects them. To understand the criminal intelligence operations in the recruitment of sources, primarily the need to give basic knowledge of the criminal milieu.

The concept of mobility of the criminal milieu, includes all the elements and factors that build a floating island-criminal milieu. ${ }^{1}$ It also includes all krimalne roles (some authors define them as a professional, we believe that it is not accurate) members observed singly or in combination: a) that took place in a particular area within a specified period, b) or are currently taking place; c) or will happen (happen) in the future. Although the mobility of individual phenomena in the criminal milieu may be closely related to group phenomena, they are still independent in their signals and symbols, as the authors note that one of the most thought-crime-does not coincide with the group and do not appear (taking place, event) on the same way.

Furthermore, the observed movement of thought in criminology criminal phenomenon and is not necessarily associated with the occurrence or disappearance of, or the development of the criminal milieu. ${ }^{2}$ In rare cases, when looking at crime milieu whose activity is illegal turnover of drugs and substances psihiotropnih, matching the appearance and the milieu is not always necessary. ${ }^{3} \mathrm{It}$ is not unusual for criminal organizations and individuals grow in their organi-

$1 \quad$ Recent criminal thought holds that criminal milieu has its own collective identity crime (of course not talking here about the criminal's identities), a criminal phenomenon own individual identity. It is alleged that the makings of that collective identity: a) language, b) symbols (common or identical by some groups and levels), c) values; d) customs and norms. Also to be considered long in physical environment did not contribute substantially to the criminal milieu, the recent thought crime shall not be considered the most accurate definition and indicates that the factors of physical environment with multi-layer effect on the criminal milieu. They can be affected by: a) positive b) negative, and c) and to change its direction of movement, no matter which direction the word (referred to in the text).

2 Hagan, J., and Palloni, A, (1998). Immigration and crime in the United States. In J. P. Smith and B. Edmonston (Eds.), The immigration debate, Washington, DC: National Academy Press, p. 154.

3 Explaining the phenomenon that occurs in the criminal milieu, and the criminal market as one of the elements of the criminal milieu, after law enforcement operations, services apprehend dozens of members of criminal organizations or individuals whose criminal activity was in the illegal drug trade, that after a crash prices and increased supply in the market, because time is crime intervention, ad hoc and not integrated, which is the model that was developed in criminology known as "Darwinism"-was removed to an organization which is substituted by another. 
zation or lose "situation” and that in fact the status of phenomena occurring in the criminal milieu, even opposite changes-increased sales prices of drugs and narcotics, „give”.

The mobility of crime occurrence in the criminal milieu, and the criminal milieu is a complex phenomenon, and as noted crime scientific thought has mainly two forms (we believe that these attitudes are not quite the most accurate, because we believe that there are multiple forms). These are: a) horizontal and vertical forms of mobility. From the research we conducted for this study, found that there is a kind of mixed forms of mobility and a form that is called in criminology theory: the problem does not necessarily have a direction, which may not have elements of any shape, but also occurs within the forms, regardless of its current direction. Legal and forensic theorists still believe that a harmonious balance in the criminal milieu there, and it also means its full mobility or immobility.

Figure 1: Shows the visibility of the phenomenon in the criminal milieu, and the need for criminal intelligence in their tissues to obtain information on criminal activities, criminal organizations, and preparation of criminal offenses. ${ }^{4}$

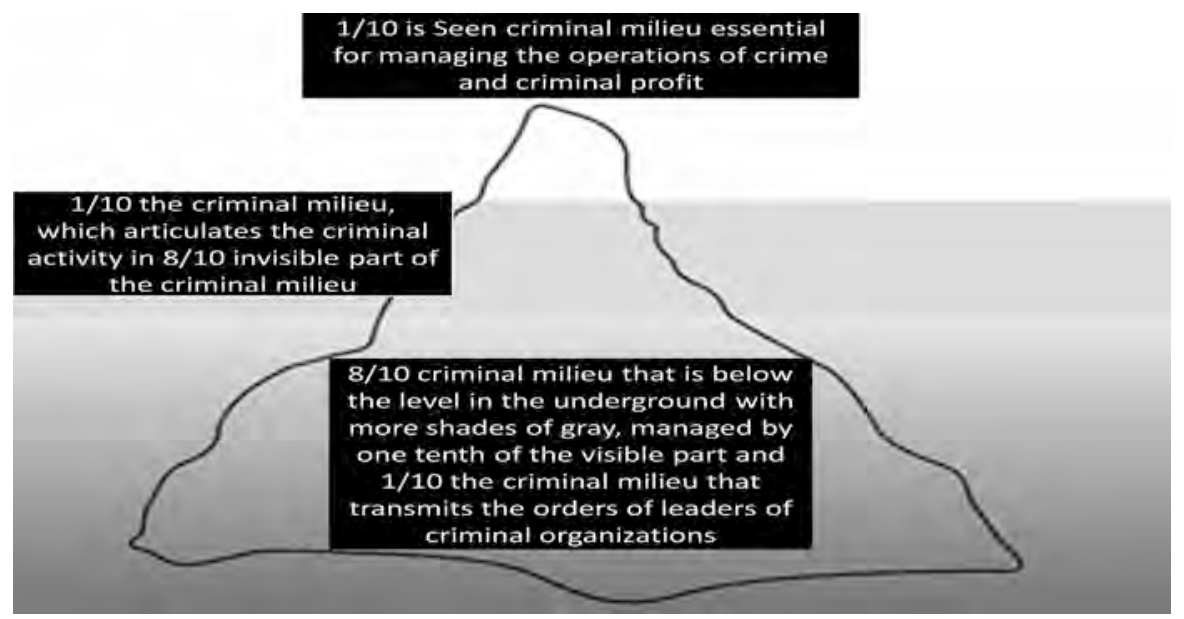

It is understood from the aspect of criminal thoughts, given that its scope does not include scientific research, criminological factors, can only be glimpsed aspects of the mobility of crime occurrences in the criminal milieu, and the criminal milieu, the crime level of recognition, but not the causes or conditions that cause them.

To fathom the spirit of the process in the criminal milieu and criminal entity, it is necessary response to a question about the criminal milieu? This in no way criminalistics scientific thought with simple terms, we will counter the current criminal thoughts which sought to definitions, as they approach the definition

4 Data were derived based on research conducted by the authors in Serbia in the period 2000 to 2010 , in the criminal milieu. 
of the Romans did, but without giving the definition of content that builds a specific term. ${ }^{5}$ It is also a requirement to demonstrate not only what the criminal milieu, and what he is now, but what will he be in the future. When he failed science and criminal legal thinking on this issue, then exposing the criminal milieu and criminal phenomenon may be deprived of reasonable methodological order and scientific consistency. The first thing noticed is the multiple meanings and conceptual intricacies of crime definition of this phenomenon.

This leads us to conclude that the crime milieu exerted its vagueness and its complexity, it is quite true. As a society, a dynamic category, as a kind of "process" criminal milieu is different in different times defined. Criminal milieu could be said to date from the determined point (the point) several scientific disciplines.

To further study determined the essence of crime intelligence point of recognizing the criminal milieu, and his appearance in and out, it is necessary to first examine the crime scene in modern thought the point of the criminal milieu and criminal phenomenon and the differences between them. ${ }^{6}$ On the other hand, thought crime shows: if we hold the view that the criminalists to suggest that criminal phenomena that we observe in the criminal milieu, a product section and the effects of unknown factors that part of the famous floating islands, quite correctly, to respond to a question on developments in the criminal milieu, we must find out criminal phenomena not wholly visible from their side, but with their inner invisible hand.

\section{Definition of Criminalistics intelligence source}

The challenge that criminal carries in it self requires a skilful and strong answer, and each answer is conditioned by timely information. ${ }^{7}$ A piece of information coming from the criminal milieu is the key, not only for considering the current problem, but also for predicting a criminal offence. Therefore the information coming from the criminal milieu is necessary for determining time

5 Crime shows that the above point by a reasonable thought crime does not go in their scientific research in the criminological and sociological aspects of the occurrence of the criminal milieu. On the other hand indicate criminal that does not mean that the results of criminological research are important for understanding the occurrence of crime and the criminal milieu, on the contrary.

6 If you see a group of people running and one in front of it, criminologists, based on external observations may at first appear to define the character, if no knowledge about the characteristics of the criminal milieu in which the phenomenon observed. Therefore, due to lack of knowledge about the character of the milieu in which observed this phenomenon criminologists might think: a) it was a lynching; b) frantically to escape to the unknown, and others.

7 Manojlović, D."Good operation surce, good case. Bad operation source, bad case. No operation source, no case." .... (Police saying)... 
and conditions for an optimal reaction to crime. ${ }^{8}$ This study will follow through meeting and conditioning of these two facts, for it summarises- the development of criminal activity on one hand, and on the other, the need for detecting and proving the same activity at court.

Processing the issues of operation sources, taking into consideration their operational aspect and the possibility of their application when detecting criminal activities, will not process the issues of undercover investigators, agent provocateurs, confidants or a man of the prosecutor's office. What is important to understand here is that both an agent provocateur and an undercover investigator, as well as a man of the prosecutor's office, can be operation sources; yet, in these cases using sources in investigating actions ${ }^{9}$ is possible, whereas operation source used for collecting operation knowledge does not have the possibility of being a part of the investigation techniques, for it does not qualify as a source of that status. ${ }^{10}$ However, here we have to be careful, for in certain countries a transition from the operation source status for collecting operation knowledge from criminal milieu without taking part in criminal activities, into a source phase/status that takes part in committing criminal offence under certain circumstances is allowed: according to a precisely defined procedure and in a way provided by legal rules and regulations of that country. ${ }^{11}$ What is crucial here is the manner in which a criminal-law expert manages the operation source and channels its designs (authority demands). The operation activity over the source, in this case, cannot be an intervention into the individual civil rights. ${ }^{12}$

$8 \quad$ Hall, R. Higgins, O., Adams, R. (1998). The Treath from serious and Organized Crime to UK Secutity and Interests- a strategic assasment, London, 1998., National Criminal Intelligence Service, p. 21.

9 Each possible appearance of the source for collecting the information at court, which is not in any of the following category- with the participation of an undercover investigator, an agent provocateur, a man from the prosecutor's office- is a piece of irrefutable evidence that the employer acted contrary to the criminal operation combinatorics rules and regulations in force, for the source was being directed to the procedure, not to the ambient recognition of criminal occurrences and their delivery. Bringing to court an operation source that collects information without taking part in the operation is impermissible, it is a defeat, breaking of the fair-play rules, a loss of trust with the sources that are "eyes and ears" of the detection authorities... usdoj.gov

10 Howe, S. (1997). Weaknesses of intelligence, Policing Today, Izbor, 2/97.

11 In the opinion of professor Vodinelić, in Prosecution Legal Act and also in the Police Legal Act, a precise general police clause on defense against danger should be enacted, and no unnecessary secrets should be made, the air should be ventilated, thus retrieving dignity to police and visible protection to citizens...

12 A decision of the greatest importance was made by the Federal Constitution Court of Germany-..."as far as the area of crime repression is concerned the interest of keeping the execution of this task in secret may be more important than the interest of the criminal offence condition. An intervention into the legal position of a citizen should be considered appropriate, if it serves more to the direct protection of public welfare, rather than to the aims and objectives: of the state punishment demand ...”. Fijnaut, C. and Marx, G., (2001). 
Ever since the international conference, held in the city of Ohrid, in November 1993, the significance of the terms of an informant, informer and an undercover police scout, from the field of criminal operation activity has not been understood properly ${ }^{13}$. Apart from a significant delay of a few decades, significant structural changes in the dynamics of the development and movement of criminal activities cannot be perceived. ${ }^{14}$ Secondly, eyes are being shut in front of the increasing grey zone into which the detection authorities cannot infiltrate. ${ }^{15}$

Undercover: Police Surveillance in Comparative Perspective. The Hague: Kluwer Law International, p. 134.

13 Discerning between a private and intimate sphere is crucial for the functioning of a crime investigation operation source and officials managing secret crime investigation operations. Whether we will regulate this area by means of legal acts in the same way that is done in European countries, where an intervention into the intimate sphere is impermissible, and permissible for the private sphere only when there are grounds based on law, depends on the level and the power of the act which will legally regulate this area. If this area goes on being regulated by instructions, the damage will be bilateral (an intervention into the intimate personality sphere and inability to prevent the danger).

Adler, P. (1985). Wheeling and dealing. NY: Columbia Univ. Press, p. 32.

15 The Importance of Following the Confidential Informant Narcotic Arrest Procedures An informant is an integral part of a narcotics arrest. However, if proper narcotic arrest procedures are not followed, than the case can be thrown out no matter how much evidence is obtained. The Identity of the Confidential Informant-Law enforcement should not reveal the identity of the informant to anyone to protect the informant from harm. A prosecutor might not know the informant's identity. However, under certain circumstances, the informant's identity can be revealed if a judge or magistrate orders it. Procedures: According to the informant manual for the city of Los Angeles, California, a confidential informant who has come into contact with narcotics through a purchase, assisting officers in a narcotics operation or any other reason, shall immediately be searched for narcotics once the operation has been completed, and the results of the search shall be documented in writing; An informant must provide law enforcement reliable information that can be corroborated by another witness; The informant should provide law enforcement with eyewitness accounts of any drug-related criminal acts, vital background information on the suspects and their narcotic criminal activity and contacts, critical intelligence to help support the investigation in obtaining a search warrant, the identity of valuable witnesses or leads that will cooperate and important testimony during trial, which will help the prosecution convict those arrested; The informant should provide accurate and complete information, keep all intelligence gathered confidential, never discuss any part of the investigation with anyone, never pursue suspects through entrapment, must be a lawabiding citizen (if the informant is a criminal once retained, they must immediately cease and desist any criminal activity), never violate the rights of any subject of the investigation and never place themselves or anyone else in harm's way; The prosecutor should always have an additional person present whenever meeting with a confidential informant; The prosecutor should review any findings provided by the informant with law enforcement to determine whether the information provided can be relied on, whether the informant has the means to provide critical information relevant to the narcotics investigation, whether promises were made to the informant by law enforcement or the prosecutor and whether their background includes criminal activity. (author noted...) 
The lack of understanding that the "core" of the struggle against criminal activities lies not only and solely in directing to the organized criminal activity, but also and a lot more directing onto general criminal activity, significantly reduces operation work competence, making it "unproductive" when it comes to its function ${ }^{16}$ In order to act in the pre-field of criminal activities in respect of preventive consequence restrain ${ }^{17}$ - for a potential harmed party,far-reaching information is essential (certain authors take a standpoint that even some of the weak information could be accepted), the information is permanently gathered , indicating the trend in criminal activity and crime itself. This can be guaranteed only by a new strategic orientation- reliable processing of the reliable operation material, managed in a way which meets the criteria of "modern" currents and criminal activities. The separate strategy equals taking a step back. On the contrary, modern aspirations originating on the basis of comprehensive research, indispensably require developing operation sources on a global level with a unique organizational form (starting from recruiting to security, for that is what the development of criminal milieu dictates), or the simple lack of it.

Defining source as a "well-intended citizen who provides information and data of interest to the Service voluntarily, or "a person who consciously, in an organized and secret way gives out information, data and other facts to the Criminal Activities Service, that is to say, to its agents," is an outdated specification that has been in use for more than six decades. This clearly stresses the necessity of precise legal regulation of operation activities, so as to reduce the "grey zone" of these activities as much as possible. The course of action should be directed in a way which would make it possible for a catalogue of procedures and principles to determine explicitly, precisely and comprehensively the legal basis of operation activity with sources and their involvement. Modern democratic choices should try to recast the regulations on operation authorizations from the Police Law into the Criminal Action Legal Act, by which dignity of the highest possible legal quality would be given to them, for precisely the Criminal Action Legal Act represents the concretization of constitutionally-legal regulations in the crime field. ${ }^{18}$

16 Today, in Europe, there is a general understanding that an operation activity is a successful way towards confronting criminal activities, by means of creating an operation network, which is at the same time followed by explicitly legally regulated area, starting from recruiting, leading and managing, securing to registering and recruiting an operation source. All criminal agencies build their service on reliable information, as well as the strategy of the future direction for the development of structures and police service, taken from Howe, S., (1997). Weaknesses of intelligence, Policing Today, New York, p. 17.

17 Manojlović, D. (2006). Theoretical and practical aspects of criminal investigation and intelligence sources, Security, No. 2/06. MUP RS, Belgrade, p. 11.

18 Водинелић, В. (1994). Проблематика криминалистичко-тактичких института информант, информатор и прикривени полицијски извиђач у демократској држави II део, “Безбедност”, Београд, број 2/94. 


\section{Criminalistics intelligence sources-phenomenology}

It is not necessary to examine minutely and essentially "the labyrinth of operation activities." In order to notice the fundamental significance, the source has in the functioning of detecting authority. The operation source is in the initial phase of gathering information. In criminology there is a common standpoint which can be summarized in the following statement: the quality of operation action is in a direct proportion to the quality of the operation source, ${ }^{19}$ in correlation to the same $e^{20}$. That is the reason why a large number of European countries have started passing legal rules ${ }^{21}$ in the field of operation sources, no matter whether we talk about a human or technical source, which should lead us to the adequate principles and procedures when choosing, recruiting, preparing, hiring, leading and securing the source. Passing written acts from this field should enable state authorities: to improve ethical principles in relation to this most sensitive operational action/criminal investigation operation; to gather operation information more successively; to use and exploit the gathered information; to manage the source itself better, based on his/her sphere of activities; to infiltrate more efficiently into the criminal surrounding; to gather operation data with or without participation of the source directly; to create up preventive researches for cutting off criminal actions of networks, individuals, organizations; an early warning; to create studies of criminal action trends and crime forms; to "stretch" the time of criminal investigation in advance. ${ }^{22}$

\section{Comparative approaches in criminalistics theory}

Theoretical and practical criminal experiences in European countries can be summarized in the following-criminal action and ensuring evidence at the beginning of criminal action, of an individual or a criminal group, have a crucial meaning when it comes to the outcome of criminal operation, especially in cutting

19 Greer, S. (2001). 'Towards a sociological model of the police informant.' The American Journal of Sociology, p. 46(3).

20 Some of the authors go even further and take standpoints that imply that without the operation source that they call "golden source," it is impossible to count more precisely and with greater certainty on crime control: Bowman, M. E. (2005). Intelligence and International Law, 2005., Swenson, R. G.: Intelligence Education Smith, A.: „IntelligenceLed Policing: International Perspectives on Policing in the 21st 2005. p. 63.

21 Водинелић, В. (1994). Проблематика криминалистичко-тактичких института информант, информатор и прикривени полицијски извиђач у демократској држави II део, "Безбедност“, број 2/94, Београд.

22 Fatić, A. (1997). Kriminal i društvena kontrola u istočnoj Evropi, "Institut za međunarodnu politiku i privredu", Belgrade, str. 3 . 
off the action ${ }^{23}$ so as not to lead to the intended consequence and the latter managing of the prosecution. The criminal analysis of the performed criminal offences in European proportions displays that the criminal activity does not occur spontaneously, but the same is planned in advance. ${ }^{24}$ When the function of an operation source is being described and determined, the same can be understood in the following way: firstly, the criminal operation source has a function in taking precautions (preventive measures) in preventing criminal activity from forming and manifesting, secondly, it should reduce criminal activities to the least possible measure and thirdly, the criminal operation should be unobtrusive.

Furthermore, it is implied that in order to make "the narrowing" of criminal activities possible, the first assumption is a timely gathering of operational information; the second assumption is that state authority has an operational capacity to conduct its operation in that direction. From an operational aspect, there are numerous methods by which operational information ${ }^{25}$ can be gathered (findings, data, information, etc.) along with the proofs of criminal activities, apart from the phenomenological characteristic of those activities to be undercover in the pre-field of execution (preparation), in the field of execution and after the execution of a criminal offence. In our opinion, it is possible to expect a higher degree of effectiveness when confronting all the forms of criminal activity, if the methods by which it would be possible not to break into the protected area of human rights and freedoms. We take a standpoint that in finding the bridge between the three fields of activity, which aspire to the same aim: a) civil rights to undisturbed enjoying human rights and freedoms; b) to their justified and legally based demand to be safe; c) in preservation of the justified interest of the damaged party there is room for a criminal operation source and operational IQ. One of the equally important issues being considered in criminal theory is how to organize the action of operation sources in a vertical or horizontal structure. ${ }^{26}$

$23 \quad$ Adderley, R. W. Musgrove, P. (2001). Police crime recording and investigation systeme, Policing, p. 28.

24 Sshurholz, F. H. (1999). Intensivierte Finanzermittlungen mit dem Ziel der Veomogensabschopfung, Zwischenbericht zem Pilotprojekt dre baden-wurttemberischen Polizei, 9/99., sz. 257-261. (259).

25 Robertson, K. G. (2003). Canadian Intelligence Policy: The Role and Future of CSIS, p. 19.

26 Another useful typology is presented by Weston \& Lushbaugh (2003) who distinguish the usefulness of the informant as well as the quality of their information: basic lead informant -- usually a friend or acquaintance of a criminal with any number of possible motives who is most useful and accurate at revealing the whereabouts or geographical location of persons or property; participant informant -- usually a go-between or arrestee turned informant who helps police instigate a drug sting or reverse transaction or lure a suspect into surveillance; covert informant -- usually someone deep inside a criminal organization with a falling out or difference of opinion and wants to provide spot intelligence over a period of time as long as their identity is protected and a pleasant future guaranteed for them; accomplice-witness informant -- usually a co-defendant in a criminal case who agrees to testify for the prosecution and/or do one last undercover operation (by being Vol. 11, No 1, 2014: 147-170 
In other words, most of the operation activities (including criminal agencies) are organized according to the organizational structure of the service, that is to say, a vertical principle of activity ensures delimitation and coordination of the activities, that is, the order in making decisions and decisions capacity. By a horizontal principle of performing operation activities, procedures and work technology are satisfied (structure activities).

Namely, the modern age is characterized by fast development in all criminal activities; leaps in that field are incomparably faster and bigger than progress in the development of operational structures and activities. All this requires a constant adjustment of structures and jobs. What should always be taken into account is the fact that the structure of operation activities depicts everything those jobs represent- a purpose, aims, methods and means, and that, from the aspect of success in confronting criminal actions has a decisive role with hiring a source. In European countries in theory and professional practice on operation activity, it is implied that the activity is very dynamic and in its phases mutually dependent process, so that all the structures in the jobs chain have to stand in a tight causal connection. Criminal operation work is observed as a process with three key components: a) gathering operation information; b) processing operation information; and c) use or usage of this information. Broader and more appropriate observation that has been accepted in defining operation actions, indicates to us that the three-element process represents too narrow an understanding of operation work, for in this operation work the unavoidable elements are: managing and working with the sources, means, application of the operation technique, development and managing of the operations, etc. A certain number of experts in the field of criminal operation activities and services in Europe, claim that a cycle of criminal operation work starts by recruiting the source, whereas others believe that it starts by gathering information which goes alongside with processing the already gathered data. ${ }^{27}$ This observation is more appropriate for modern operation activity, for it builds a constant process, which in its functioning includes guiding as well.

\section{Criminalistics intelligence sources the criminal mileu-approaches in theory}

To allow hiring and using operation sources is disputable nowhere in the world, in principle. In fact, it is believed that authorities for detection have authorizations to gather information from every citizen who does that without being forced and is also in a situation to obtain the information. The constant enforcement of the feelings of necessity for respecting human rights and freedoms

wired for sound) in return to the package deal of immunity and the witness protection plan.. Weston \& Lushbaugh, 2003.(author noted)...

27 The EU Council decided at Ist meeting Tempere, 1999. 
of citizens requires legal regulation of this area of interest. ${ }^{28}$ The regulated area of operation sources would solve this dilemma: whether the operation source controlled by an official, who organizes it, guides it and controls it in gathering information, extends to the individual sphere of the citizen. Or, for working with operation sources of this kind, it is necessary for public servants only to be presented with the task of "repressing the crime" following the Police Law and Prosecution Legal Act, which should once again require explicit legal regulation, avoiding the up-to-date determinants to "take the necessary measures"- not stating clearly which ones. This kind of definition is imprecise and it leaves open the possibility for arbitrary interpretation by public servants, together with the risk to be responsible for the decision made in the best faith, for the Public Attorney believes that the action could have been carried out "in a different way," which also is not being clearly defined. Thus, avoiding ambiguity is essential. Most specifically, this area should be legally regulated in such a way so that the official who conducts the operation activity by hiring an operation source, who complies with the assigned principles and procedures of the employer, enjoys absolute protection. ${ }^{29}$

\section{Dimensioning aspects of operation sources}

In criminal activity, the operation source makes a significant constituent part of the operation activity. As such, it is a part of every operation system/ process of every criminal agency in the world. Activity results of the operation source in the form of concrete, action operation information ${ }^{30}$ make an operation process input in controlling criminal occurrences, criminal milieu and criminal activities. ${ }^{31}$ Therefore there is a general opinion that the operation scaling could

$28 \quad$ Frank, C. (2000). Strategic intelligence secret world an antology, London, p.15.

29 Operation Department officials- of the Federal Bureau of Investigation, in applying secret operations measures with sources, following the assigned principles and procedures of the employer (FBI), are protected from the secret service influence, and the official prosecution is out of the question, when the board determines that the official has behaved according to the assigned instructions. This legally regulated course of action builds up the capacity and dignity of the service and a public servant himself, creating trust and assurance that if he follows the assigned rules, he will have all the necessary protection. This kind of regulation is a vital necessity for the course of action of any official in Serbia. The current state of this field in Serbia can be summarized in a saying "wash the cloth, but be careful not to get it wet." (author noted)...

30 Castells, M.(2004). End of Millennium. The Information Age: Economy, Society and Culture, Vol. 3, Oxford: Blackwell, p.72.

31 Finally, there is the oldest typology of motives which has been around for some 40 years simply because they never change (Harney \& Cross 1960): fear -- people who feel threatened by the law or by other criminals (most police believe this is the best motivation); revenge -- people, like ex-wives, ex-girlfriends, ex-employers, ex-associates, or ex-custom-

Vol. 11, No 1, 2014: 147-170 
and should be defined in two dimensions: a) in space and b) in time. Authors wonder what implies to these two dimensions and they give an answer. Firstly, it is implied that the operation source should be distributed on the whole territory, both national and international, and that it should completely "cover" all the relevant states and movements in the criminal milieu. Secondly, as the authors notice, it requires also its presence in all the three criminal milieu dimensions: a) the past; b) the present and c) the future. ${ }^{32}$

How do these two dimensions reflect themselves on the activity and the tasks of the operation source? Space dimensioning is achieved as: a) gathering operation information from the internal surroundings (criminal milieu) inside the level of responsibility and approach to criminal activities inside the state borders; b) gathering information from external surroundings (criminal milieu) on the international level; and c) gathering information by means of the problem approach independently from either internal or external criminal milieu.

Time dimensioning is achieved, as a) gathering information through identification of occurrences in the criminal milieu which indicate the future criminal activity which still has not been developed; b) gathering information on the current state of criminal activities in the criminal milieu; and c) gathering information on the up-to-date criminal activities and the changes in that matter.

Thus, dimensioning the operation source is seen as "screening" the stimuli which will develop a potential criminal activity, the stimuli originating from the external or the internal surroundings, and enabling the stimuli "decryption." On the other hand, we would say that we see and determine dimensioning of the operating source: as diagnosis of the position of the criminal activity and criminal actions and the criminal milieu itself, but also the competence, knowledge and possibilities of agencies for their control and detection. We are at the standpoint which we may summarize as follows: the criminal operation source should be put in three dimensions: of space, time but also of the problem. We believe that from denominators which may be understood in the world criminal theory, that the source dimensioning on two levels is insufficient for comprehending the scope of its activity. Therefore, we believe that the attitudes

ers who want to get even; ego -- people who need to feel they are smart "big shots" and/ or outwitting those they see as inferiors; money -- people who, like mercenaries, will do whatever it takes if the money is right; repentance -- people who want to leave the world of crime behind them and/or citizens fed up with crime. (author noted)...

32 The snitches, the basis of DEA in Mexico. In the fight against drug trafficking and organized crime, said Michael Braun, who until October 2008 directed the U.S. anti-narcotics operations. Braun, who left the DEA after 33 years of service and now a consultant in the field of combating terrorism and organized crime, says U.S. agents do not protect any Mexican cartel. In an interview with Proceso, the expert points out: "The key to success in the fight against drug trafficking has always been the intelligence obtained through people, ie through confidential informants. This is and always will be. "Informants play many important roles: they take part in covert operations, steal information, help to place microphones and get phone numbers to track criminals."(author noted)... 
on spatial and temporal dimensioning are acceptable, but not sufficient as well. Problem dimensioning is necessary, for one criminal activity can only be traced in a problem dimension, both from the aspect of space and the aspect of time, e.g. overseeing an activity inside a criminal organization or a criminal milieu, but not the criminal milieu and criminal organization.

\section{Movement models of the criminalistics intelligence source}

One of the important aspects of the operation source activity is the model of its "movement". Based on the modern views in criminal theory, the movement of an operation source is observed from a few aspects: a) non-endangering or cooperative movement; b) endangering movement; and c) defensive movement. Non-endangering, or how we else define it in criminal theory, cooperative movement of an operation source is divided into: 1)the movement that enhances the source position; 2) movement that enhances the criminal agency position; and 3) movement that improves the methods of collecting information from a criminal milieu. ${ }^{33}$

From the theoretical aspect, these movements may be: a) offensive; or b) defensive. Defensive movements of the operation source are the so called responsive movements, that is to say, a reaction of an operation source on the actions of the participants in a criminal milieu, which may be further divided into: a) an action prior to an offence being committed; b) a reaction after an offence has been committed; and c) an action while an offence is being committed. We are of the opinion that this division of the movement aspect of the source is insufficient to cover all the movement models in the responsive movement, adding that we must not forget lag in retaliation - halt or how it can be also found in theorya halt in the source reaction, by which we imply the time that passes from the moment of action in the criminal milieu in all the aspects of activities till the time of the operation source activity.

When we talk about endangering movements in criminal theory, for a parameter by which we express that movement we consider the following: a) whether the position of the source in that criminal milieu is endangered by the same; b) whether the source complies with the rules that were intended for its activity; c) whether the configuration of the criminal milieu is acceptable for the source profile; and d) whether there is an assigned coordination of the leader and the source. The coordination has the moving instruments: a) from the zero unacceptable option, in fact, there is no activity coordination between the source and the leader; b) over the option of the acceptable scope of coordination action

33 Here, we talk about the thing that is in the criminal theory known as "the regular" system of scanning and recording the criminal milieu. So, we understand that the issue here is not about being legal or illegal, for both models are legal.(author noted)... 
with the leader; and c) to the option of differentiating which implies taking over the activity based on the estimation of possibility for returning the source to the acceptable options activity.

\section{Criminalistics intelligence methodology constructing of the criminal underworld}

One of the most complex activities in the criminal operational activity is producing a profile of a criminal milieu, object or a subject of investigation and the operation source itself that would offer answers to many asked questions. There is a belief that making a source profile must be carried out in a few independent, and yet linked steps. ${ }^{34}$ The first step in making the profile of a criminal source, criminal milieu or a criminal object or subject of the operation investigation, should be the answer to the question: for what, that is, for whom is the profile intended? This question is actually the issue of the profile intention, which relates the act of making the profile ${ }^{35}$ to the operation decision that should be made based on the same. The second step is defined in the question: what should a profile contain? The operation profile may have different content, e.g. general or exactly determined which is conditioned by a concrete decision that should be made. It is believed in criminology that the profile should be concrete and specific as much as possible, and the data entered concise and precise, so as to be relevant solely for the subject or object in the scope of the investigation. The next important step is defined in the question: which sources for making a profile should we use? Here we should, from the aspect of criminal theory, use internal operation sources that are stored in the operation base of the agencies. Only after consulting internal sources we should move on to investigating and using information from the external resources. A certain number of authors believe that these two actions should be conducted simultaneously, from an operational aspect. Next, or the third step is using weak information (in theory, we can still find weak information, but that is not the same). In theory, the general opinion is that using weak information does not guarantee that we will make a good profile of an operation source or milieu, for the information sources in question are either not tested or really difficult to test.

The advocates of this criminal term of "hard approach, that is, the approach of making a profile from verified operation sources" ${ }^{36}$ believe that if the profile is based, ho matter how partly, on this information, it is flawed, that is, neither valid nor reliable, so it can inflict more harm than bring benefit. Respectively,

\footnotetext{
34 Cannavale, F. (1976). Witness cooperation. Lexington: Lexington Books, 1976.

35 Јовић, В.(2004). Криминалистичко-обавештајни рад, појам и криминалистички аспект, Правни факултет, Крагујевац, 2004, str. 29.

36 Billingsley, T. and Bean, T. (2001). Informers. Portland: Willan, p. 123.
} 
they believe that it can take the operation action to the wrong operation source. On the other hand, a great number of theoreticians in criminology believe that weak information must not be excluded in advance from the operation material for making a profile. Furthermore, they point out that a criminologist who makes a profile will not always have "firm information" which is supported by the authenticity of the source. In order to make a difference between the confirmed operative information which has gone through the estimation according to the criterion of the source assessment and information from the source, we will offer that of what weak information are made, those being: rumors, opinions, personal attitudes, etc. If we could define making of the operation profile of the source and milieu, based on the given facts, how would we do it? Using the so far knowledge, we will define operation profile as: the sum of very delicate, planned and professionally carried out operation activities on gathering operational information that could help the operation source performance.

\section{Phenomenological aspects the findings from crinminalistics intelligence sources}

The information obtained from the source is determined, in the following way, as "information for action" and, depending on the information value estimation, it receives the status based on the levels of protection- a) "must know"; b) "needs to know" c) "should know"; d) "can know" e) "cannot know." Operation information ${ }^{37}$ from the source is mostly delivered in the form of a report, without any possibility of finding out how the information is obtained, due to the fact that the information may be presented only in person and transmitted under the system of protection, never openly. ${ }^{38}$ Introduction or register part of the operation information ${ }^{39}$ is being encoded, so that the key stays in the hands of the source managing official, and all the others who are familiar with the text according to the scale, where the key identification signs are closed. Based on the level of grading, an entrance is allowed- an insight into the information, in a way that the unity of knowledge is not disturbed and it does not leave the subject of knowledge.

Furthermore, it is indicated in criminal theory that the information from the source may be, apart from being secret and public: a) outdated; b) general; c) valid; e) invalid;f) examined; g) unexamined; h) reliable; i) unreliable, etc. When it has been clearly defined in criminal theory from what sources information can be obtained, the sources are as follows: secondary, primary, closed, open, basic,

\footnotetext{
37 Brown, M. (1985). “Criminal informants.” Journal of Police Science and Administration, p. 14.

38 O’ Connor, T. (2003). "Surveillance” and "Wiretapping.” Pp. 624-629 \& pp. 710-712 in R. Carlisle (ed.) The Encyclopedia of Intelligence and Counterintelligence, Vol 2. NY: Golson Books, p. 2.
}

39 Carroll, J. (1975). Confidential information sources. Los Angeles: Security World, p. 36. 
creative, human, technical, etc. Apart from the stated, criminal theory implies that the knowledge is obtained from the operation source from many levels: 1) from the source for ad hoc operation investigation; 2) from the source for the urgent investigation; 3) from the source for fundamental operation investigation; 4) the sources for strategic operation investigation; 5) source for tactful operation investigation. The entire listed criminal operation source can be centralized or decentralized.

\section{Value of knowledge of crimninalistics intelligence sources}

Another aspect of the operation knowledge from the source is very important for criminal agencies in general that are in charge of, or in the jurisdiction of which is, detecting criminal activities and gathering evidence. This aspect of operation knowledge implies creating abilities in a criminal agency so that it would be as a unified structure capable of forming new operation knowledge, to expand it through the whole agency towards every employee, and embody the same into the operation activity of higher quality and its products.

In world criminal literature, books and articles, we may recognize a standpoint that the objective of criminal agencies should be, increasing operation knowledge ${ }^{40}$ of an agency as a basic support to every operational activity. In addition, in criminal theory it is believed that every criminal agency, when we talk about the operation work, has its own operation IQ. How do we estimate whether and to what extent is one criminal agency intelligent? IQ of a criminal agency is as high as the same is capable to prevent criminal activity, is one of the opinions of criminal theory. And the operation $\mathrm{IQ}^{41}$ of the agency official is as high to that degree as: each official gathers valid knowledge, data and information, on one hand, and how high a quality operation network of the source is, on the other hand. Any other operational knowledge that is based on technical sources (tapping, tracking, etc.) or the knowledge obtained on the basis of the operation knowledge after the performed criminal offence is not the operational IQ, but rather the instrumental-work knowledge, which is, technically speaking, a part of the first operation IQ, that is, the knowledge of "lower" operation quality. The operation activity, and in that sense criminal agencies themselves, where the priority is given to the first IQ, are the agencies with the perspective development of knowledge and the quality for the protection of citizens and their assets.

In the world and in a great number of countries, the first level operation knowledge has the status of a "golden wire", which is a condition for a timely and

$40 \quad$ Hans, J. E. (2000). Intelligence a new look, New York, p. 9.

${ }^{41}$ It is clear that here we do not talk about the IQ as the intelligence of an individual, that can be quite high, high, above the average, average, below the average. (author noted)... 
quality action of the agencies. ${ }^{42}$ In view of the above discussed and displayed, it is believed that in criminal theory there are no obstacles and that each criminal agency asks itself questions in order to determine its current level and the future operation knowledge- IQ, on one hand, and its operation intellectual ${ }^{43}$ capital on the other. The basic question that we ask ourselves is: is the criminal agency operationally intelligent? In order to get the answer to this question, it is necessary to ask a few questions. Firstly, whether the agency uses and applies methodology and the methods by which we increase the level of the operation IQ? Secondly, whether the agency realizes that the present and future operation activity in the criminal milieu is conditioned by high operation IQ? Thirdly, whether the agency measures to what extent the officials build up their operational IQ- professional knowledge- the quality of that knowledge? Fourthly, how much has the criminal agency IQ of been making the conversion of the criminal milieu secrecy into the operation knowledge, data and information? Fifthly, how big is the ratio of the knowledge conversion into data and the operation data into the operational information, and later on into analytical operational information with the IQ agency? Sixthly, how big is the ratio between the conversion of the operation knowledge, data and information into material information as IQ of the operation activity of the agency? Seventhly, what is the conversion ratio of the material information into evidence as the product of the agency operation action? And finally, the eighth question, what is the ratio between submitted charges to the Public Attorney and the charges in favour of the guilty verdicts, which is the product of the IQ agency? The eight question is the crucial question of the criminal agency IQ operation - does it do the right things and does it do them in the right manner? All the issues are defined by IQ agencies, and not only them, but also the officials, primarily the managing officials.

\section{Secrets of criminalistics intelligence operations}

Understandably and justifiably from the aspect of this research, before we would give any specification of the operation contact we should define secret activities in operation activity. From the aspect of criminalistic operation activities, a secret operation activity is defined as any kind of activity or operation criminal action ${ }^{44}$ that includes the need of the operation source, regardless of the fact whether we have a human or technical source, which requires the application of the disguised ${ }^{45}$ (legendary identity) by a criminal agency official, who on behalf of the criminal agency undertakes the activity regulated by law or any

\footnotetext{
42 Miller, G. (1987). “Observations on police undercover work” Criminology 25:27-46.

43 What is criminal intelligence, National Police Academy, Oslo, 2006.

44 Hight, J. (2000). “Working with informants.” FBI Law Enforcement Bulletin (Sept.): 15-20. (18)..

45 Dempsey, J. (2003). Introduction to investigations, Belmont: Wadsworth, p. 20, 21.
} 
other kind of legal act. This kind of secret criminal operation activity is most commonly carried out as part of the secret operations, ${ }^{46}$ and is also carried out individually as an isolated operation task. ${ }^{47}$

Next institute without which this research would not have a methodological approach is criminal theory specification, of the secret crime operation institute, in the scope of which a secret operation activity of recruiting and engaging is being carried out, alongside with the operation source managing. ${ }^{48}$ We will define secret criminal operation as, an operation activity that includes more/a series of linked secret operation activities in a certain period of time, on the part of criminal agency officials. ${ }^{49}$ The series of linked secret operation activities consists of three or more separate contacts on the part of criminal agencies officials/ recruiters, a leader or a coordinator, when the recruiting of an operation source is being carried out. ${ }^{50}$

$46 \quad$ Marx, G. (1988). Undercover. Berkeley: Univ. of CA Press, p. 35.

47 The number of intelligence informants has been substantially larger in previous years because of the "Ghetto Informant Program," which at its height comprised over 7, 000 informants. The FBI began the Ghetto Informant Program in 1967 in the context of the urban riots and violence of the mid-1960's, and in response to instructions from the White House and the Attorney General. Although "ghetto" informants were initially used as "listening posts" to provide information on the planning or organizing of riots and civil disturbances, many were eventually given specific assignments to attend public meetings of "extremists" and to identify bookstores and others distributing "extremist literature". The FBI terminated the program in 1973 after sharp debate within the Bureau over the program's effectiveness and the propriety of the listening post concept. Final Report, of the ha Select Committee to study governmental operations with respect, intelligence activities, United States Senate, april 23 (under authority of the order of April 14), 197623. The use of informants in FBI domestic intelligence investigations. See U.S. Department of Justice, The Attorney General's Guidelines regarding the Use of Confidential Informants, May 30, 2002. (author noted)...

48 Operation Babraham, May 2001 - Nov 2002 /The Investigation; Successful local Merseyside man Francis Kennedy prided himself on being a self made sharp businessman who was making millions from his alcopops business. But in truth he was the figurehead/ gang boss behind a booming drugs business that operated out of Merseyside and had major connections all over the UK, Europe and South America. The police operation, codenamed Brabraham began in May 2001 and started by picking off Kennedy's couriers one-by-one. Operation Babraham, May 2001 - Nov 2002. (author noted)...

49 Ericson, R. (2000). Making Crime: A study of detective work (2nd edition); Toronto: Butterworth, p. 41.

50 Late on October 16th 2002 Thom collected a trailer from an industrial unit in Burscough. The trailer had previously been located at a unit owned by fellow conspirators Harold Camello and Alexander Brown, on the Weaver Industrial Estate in Garston and had been fitted with a concealment under a false floor. He then drove to the Channel Tunnel and left the UK, returning on the 19th. During this same time period, Alan Gerrard flew to and from Holland. Thom was apprehended and arrested on the M74 just south of Glasgow. The truck was seized and searched by Customs officials. It was found to contain: 100 kilograms of amphetamine 64 kilograms of ecstasy (the equivalent of 150,000 tablets) 21 


\section{Criminalistics intelligence contact with the source}

The use of secret methods and techniques is not the only characteristic of operation activity. In secret criminal operations that are carried out in operation activity we include the operation contact, as well. In operation activity an operation contact is defined as a communication between a criminal agency official and a person who is not an agency employee; the communication may be: spoken, written, done on the phone or in an electronic way, which includes gathering knowledge, data or information of interest for operation activity or process investigation. ${ }^{51}$ What is of a great significance is the generally accepted standpoint in criminalistics where contacts that are made accidentally, for example, meeting on the street or any other place, are not considered to be the contact from the aspect of operation activity. On the other hand, the conversation that confirms the arranged time and place of the second meeting is considered to be the contact inside the operation activity.

When in operation activity the term "multiple contacts" is used, then a distinctive difference in the activity should be made in comparison with an operation activity. That is necessary due to the fact that a line of communications with multiple contacts upon which a line of sentences is exchanged may constitute a part of a single conversation. In order to understand whether one or more contacts are in question, we should take the following factors into consideration; a) time that has passed between the contacts; b) the number of interruptions between the messages in electronic mail; c) changes of the theme for conversation contacts.

Newer criminal views in theory until the end of the twentieth century hold a standpoint that, apart from the listed divisions, upon a contact of an agency official for control and detection of crime with a person from the surroundings (criminal milieu), we must take into consideration: 1) whether the contact has undergone a protocol in a way that legal or sublegal acts or instructions require; 2) whether the contact is the consequence of an approval; 3) whether after the contact has been made, the official has submitted a formal written act on the reasons and the contact approval; 4) whether the official has revealed the contact, only after the demand to expound the contact with the person from the criminal milieu. All this is necessary from the aspect of criminal operation activity because a special treatment of the contacts that have the status of"the contacts of

kilograms of cocaine 9 kilograms of heroin. The haul was valued at around $£ 6 \mathrm{~m}$. Following the seizure Smith, O'Toole, Gerrard, Healey, and Camello were arrested and, along with Thom, charged with Conspiracy to Supply Class A and B drugs. A subsequent search of premises owned by Healey revealed a further 40 kilograms of cannabis as well as equipment designed for used as part of a cocaine 'factory'. Operation Mac Arthur, socyberty. com (author noted)...

51 Maguire, M., Timothy J. (1995). Intelligence, Surveillance and Informants: Integrated Approaches, Editor: Barry Webb, Home Office Police Research Group, London, p. 18. 
delicate circumstances" is required. Namely, a delicate contact requires a special authorization and an approach to the source for more than one reason, which can be classified as categories, as: the duty of keeping a professional secret, a person which is tried for by any state organ, an official of any level of power or any other person who would fall into the category of delicate contacts anyway (e.g., a person from a foreign state).

\section{Summary consideration}

In theory and professional practice, it goes without saying that the criminal operation source is the heart, bloodstream and navigation device for detecting, understanding and interpreting occurrences in the criminal milieu. Moreover, the criminal operation is not only an early warning for the occurrences and their potential danger, but also the condition for detecting and collecting material evidence. The conversion of the criminal milieu hidden secrets by means of operation sources into the data or information (into the operational knowledge) is the highest operation IQ. The criminal operational knowledge is the basis for detecting and comprehending the occurrences in the criminal milieu. In criminal theory it is especially stressed out that the form of the operation activity with the source cannot be juxtaposed to the essence of the criminal agency objectives, the objectives of its operation undertaking, civil and citizen rights, ethical and legal regulations.

Many criminologists believe that good executive organs, informers or investigators owe their success to something that we call "a gift." You have surely heard that word a lot of times. When solving the most complicated cases criminologists use the term "talented", "gifted," etc. We would not dare to write this kind of paper if we do not share the modern views of criminology that each criminologist working on the jobs of the criminal milieu operation investigation and criminal activities owes his success to the operation sources. Their operation ability for good quality operation detection and understanding occurrences in the criminal milieu, announcing the operation interview, detection of criminal activities and gathering evidence, stands in a direct proportion with the quality of the operation source. 


\section{Literature}

- Adler, P. (1985): Wheeling and dealing. NY: Columbia Univ. Press.

- Adderley, R. W. Musgrove, P.(2001): Police crime recording and investigation systeme, Policing.

- Bowman, M. E. (2005): Intelligence and International Law, 2005., Swenson, R. G.: Intelligence Education Smith, A.: „Intelligence-Led Policing: International Perspectives on Policing in the 21st 2005.

- Billingsley, T. and Bean, T. (2001): Informers. Portland: Willan.

- Brown, M. (1985): „Criminal informants.” Journal of Police Science and Administration.

- Carroll, J. (1975): Confidential information sources. Los Angeles: Security World.

- Castells, M. (2004): End of Millennium. The Information Age: Economy, Society and Culture, Vol. 3, Oxford: Blackwell.

- Cannavale, F. (1976): Witness cooperation. Lexington: Lexington Books, 1976.

- Dempsey, J. (2003): Introduction to investigations, Belmont: Wadsworth.

- Ericson, R. (2000): Making Crime: A study of detective work (2nd edition); Toronto: Butterworth.

- Fatić, A. (1997): Kriminal i društvena kontrola u istočnoj Evropi, "Institut za međunarodnu politiku i privredu", Belgrade.

- Frank, C. (2000): Strategic intelligence secret world an antology, London.

- Greer, S. (2001): ,Towards a sociological model of the police informant.' The American Journal of Sociology.

- Hagan, J., and Palloni, A, (1998): Immigration and crime in the United States. In J. P. Smith and B. Edmonston (Eds.), The immigration debate, Washington, DC: National Academy Press.

- Hall, R., Higgins, O., Adams, R. (1998): The Treath from serious and Organized Crime to UK Secutity and Interests- a strategic assasment, London, 1998., National Criminal Intelligence Service.

- Hans, J. E. (2000): Intelligence a new look, New York.

- Hight, J. (2000): „Working with informants.” FBI Law Enforcement Bulletin.

- Howe, S. (1997): Weaknesses of intelligence, Policing Today, Izbor, 2/97.

- Јовић, В. (2004): Криминалистичко-обавештајни рад, појам и криминалистички аспект, Правни факултет, Крагујевац, 2004.

- Marx, G. (1988): Undercover. Berkeley: Univ. of CA Press.

- Maguire, M., Timothy J. (1995): Intelligence, Surveillance and Informants: Integrated Approaches, Editor: Barry Webb, Home Office Police Research Group, London. 
- Manojlović, D.(2006): Theoretical and practical aspects of criminal investigation and intelligence sources, Security, No. 2/06. MUP RS, Belgrade.

- Miller, G. (1987): „Observations on police undercover work” Criminology.

- O’ Connor, T. (2003): „Surveillance” and „Wiretapping.” Pp. 624-629 \& pp. 710-712 in R. Carlisle (ed.) The Encyclopedia of Intelligence and Counterintelligence, Vol 2. NY: Golson Books, p. 2.

- Robertson, K. G. (2003): Canadian Intelligence Policy: The Role and Future of CSIS, p. 19.

- Sshurholz, F. H. (1999): Intensivierte Finanzermittlungen mit dem Ziel der Veomogensabschopfung,

- Zwischenbericht zem Pilotprojekt dre baden-wurttemberischen Polizei, 9/99., sz. 257-261. (259):

- $\quad$ The EU Council decided at Ist meeting Tempere, 1999.

- Vodinelić, V. (1994): Problematika kriminalističko-taktičkih instituta - informant, informator i prikriveni policijski izviđač u demokratskoj državi II deo, „Bezbednost“, Beograd, broj 2/94. 


\section{Dr Dragan Manojlović, vanredni profesor}

Fakultet za pravo, javnu upravu i bezbednost

Megatrend univerzitet, Beograd

\section{KRIMINALNI MILJE I FENOMENOLOŠKI ASPEKTI KRIMINALISTIČKIH OBAVEŠTAJNIH IZVORA}

\section{$S$ a ž e t a k}

Rad je pisan na osnovu istraživanja koje je autor sproveo u poslednjoj deceniji dvadesetog veka i prvoj deceniji trećeg milenijuma u savremenoj naučnoj kriminalističkoj teoriji. Namera autora je da upotpuni veliku prazninu koja danas postoji u našoj naučnoj kriminalističkoj literaturi o fenomenologiji kriminalističkih obaveštajnih izvora. Sa prisustvom naučnog i stručnog izolacionizma i konzervativnog prakticizma u kriminalističkoj teoriji u nas, nikada se nisam saglašavao, i u skladu sa tim, nastojao sam da u radu što potpunije prenesem najsavremenije naučne poglede $u$ inostranoj kriminalističkoj teoriji o kriminalističkim obaveštajnim izvorima kao osnovnom alatu za razumevanje, prepoznavanje i dešifrovanje pojava u kriminalnom miljeu. Iz navedenog je sasvim logično i metodološki naučno osnovano što će prvo biti izložen opšti pristup u kriminalističkoj teoriji o kriminalnom miljeu, a zatim će se pristupiti istraživanju kriminalističkih obaveštajnih izvora, od njihovog određenja, preko kategorizacije, do kretanja i vođenja. Iz rezultata istraživanja nalazi ukazuju, da je tradicionalni model određenja, regrutovanja, vođenja i ugradnje izvora u kriminalni milje, koji se primenjuje u nas, napušten više od tri decenije u savremenoj kriminalističkoj naučnoj i stručnoj literaturi i praksi u svetu. Nadalje, rezultati istraživanja upućuju da je od odlučne važnosti razumevanje kriminalističkih obaveštajnih izvora, metodika ugradnje, modeli kretanja i vođenja izvora, da bi se iz kriminalnog miljea mogle razumeti pojave koje nisu vidljive, a u sebi nose izazove, rizike i pretnje. Rad kriminalističkih obaveštajnih službi u kriminalnom miljeu odvija se kroz nekoliko vrsta aktivnosti: regrutovanje, ugradnju, vođenje, zaštitu izvora i prikupljanje saznanja iz izvora. Nije više u savremenom shvatanju potreba društva da se suprotstavi kriminalnim aktivnostima pojedinaca ili grupa; dovoljno imati informatora ili saradnika. Danas je neophodno svetu kriminala suprotstaviti brojnu, dobro organizovanu i stručnu kriminalističku obaveštajnu delatnost.

Ključne reči: kriminalni milje, kriminalistički obaveštajni izvor, regrutovanje, dimenzionisanje, kretanje izvora 